\title{
A CALIBRATION-FREE EVAPOTRANSPIRATION MAPPING TECHNIQUE FOR SPATIALLY-DISTRIBUTED REGIONAL-SCALE HYDROLOGIC MODELING
}

\author{
JOZSEF SZILAGYI ${ }^{\left.1,2^{*}\right)}$, AKOS KOVACS ${ }^{1)}$ \\ ${ }^{1)}$ Department of Hydraulic and Water Resources Engineering, Budapest University of Technology and Economics (BUTE), \\ H-1111 Muegyetem Rakpart 3-9, Budapest, Hungary. \\ ${ }^{2 *}$ School of Natural Resources, University of Nebraska-Lincoln, 3310 Holdrege Street, Lincoln, Nebraska, USA; \\ Mailto: jszilagyi1@unl.edu
}

Monthly evapotranspiration (ET) rates over Hungary for 2000-2008 are mapped at a spatial scale of about $1 \mathrm{~km}$ with the help of MODIS daytime land surface temperature as well as sunshine duration, air temperature and humidity data. Mapping is achieved by a linear transformation of MODIS daytime land surface temperature values employing the complementary relationship of evaporation. Validation of the ET rates has been performed at spatial scales spanning almost three magnitudes from a few hundred meters to about a hundred kilometers employing eddy-covariance (EC) measurements and catchment water balance closures. Typically the unbiased ET estimates are within $15 \%$ of EC values at a monthly basis, within $7 \%$ at an annual, and within only a few percent at a multi-year basis. The ET estimates yield an especially remarkable match (relative error of $0.2 \%, \mathrm{R}^{2}=0.95$ ) with high-tower EC measurements at a monthly basis. The spatial distribution of the ET estimates confirm earlier, complex regional hydrologic model results and observations as well as yields a perfect estimate of the country's precipitation recycling index (the ratio of the multi-year mean ET and precipitation rates spatially aggregated for the whole country) of $89.2 \%$ vs an observed value of $89.6 \%$. The CREMAP method is very simple, easy to implement, requires minimal data, calibration-free, and works accurately when conditions for the complementary relationship are met.

KEY WORDS: Spatially Distributed Evapotranspiration, Complementary Relationship of Evaporation, MODIS Data.

József Szilágyi, Ákos Kovács: TECHNIKA MAPOVANIA EVAPOTRANSPIRÁCIE BEZ POTREBY KALIBRÁCIE PRE MODELOVANIE PRIESTOROVO DISTRIBUOVANÝMI MODELMI V REGIONÁLNEJ MIERKE. J. Hydrol. Hydromech., 59, 2011, 2; 32 lit., 12 obr., 2 tab.

Pomocou údajov ročlenených podl'a MODIS (moderate resolution imaging spectroradiometer), s využitím dennej povrchovej teploty, trvania slnečného svitu, teploty vzduchu a jeho vlhkosti boli zostrojené mapy mesačnej evapotranspirácie (ET) Mad’arska pre roky 2000-2008 s priestorovým rozlíšením približne $1 \mathrm{~km}$. Mapovanie bolo zrealizované lineárnou transformáciou MODIS dennej teploty povrchu s uvážením doplňujúceho vzt’ahu pre evapotranspiráciu CR, navrhnutou Bouchetom (1963). Výsledky dosiahnuté touto metódou boli verifikované $\mathrm{v}$ priestorovej mierke pokrývajúcej tri rády od niekol'kých stoviek metrov po stovky kilometrov, použijúc merania metódou pulzácií (eddy covariance, EC), a bilanciou vody v koncovom profile povodí. Typicky, hodnoty ET sú v medziach $15 \%$ mesačných hodnôt EC a $7 \%$ ročných hodnôt a len v medziach niekol'kých percent viacročných hodnôt evapotranspirácie, ktoré boli určené inými metódami. Hodnoty ET sú v dobrej zhode s výsledkami meraní ET na vysokej veži metódou EC (relatívna chyba $0.2 \%, \mathrm{R}^{2}=0,95$ ). Priestorové rozdelenia vypočítaných hodnôt ET potvrdzujú predchádzajúce výsledky modelovania regionálnymi modelmi, ako aj hodnoty indexu recyklácie zrážok krajiny (precipitation recycling index), čo je pomer mnohoročnej priemernej ET a zrážok agregovaných v krajine, s hodnotou 89,2 \% vs pozorovaná hodnota 89,6 \%. Metóda CREMAP je jednoduchá, l'ahko implementovatel'ná, vyžaduje minimum vstupných hodnôt, nie je ju potrebné kalibrovat' a ked' sú splnené podmienky jej použitel'nosti, je aj dostatočne presná.

KLUÚČOVÉ SLOVÁ: priestorové rozdelenie evapotranspirácie, komplementárny vzt’ah pre evapotranspiráciu, údaje MODIS. 


\section{Introduction}

Obtaining spatially distributed accurate evapotranspiration (ET) estimates is crucial in most water balance calculations for identifying mass and energy fluxes across the area of interest (e.g., Novák and Matejka, 2000). While routine Bowenratio or eddy-covariance measurements of sensible and latent heat fluxes are typically representative of a horizontal scale of a few hundred meters (i.e., the field-scale), many hydrologic modeling take place at the regional to continental to global scales (Gusev and Novák, 2007; Novák, 2001; Parajka et al., 2004). Rather than aggregating from the field scale, which may be difficult not only from a theoretical point of view but also from a practical one when long time-periods (years or decades) are to be considered, an ET estimation technique that directly works at the required spatial scale yet, at the same time, spatially distributed may be of high practical value.

A regional-scale ET estimation method has already been proposed by Bouchet (1963) almost half a century ago employing the complementary relationship (CR) of evaporation that was subsequently formulated for practical applications predominantly by Brutsaert and Stricker (1979) and by Morton (1983), Morton et al. (1985). Briefly, the CR states that under constant available energy at the surface $\left(Q_{n}\right)$ actual $(E)$ and potential $\left(E_{p}\right)$ evapotranspiration rates are complementary, their sum yielding twice the wet-environment $\left(E_{w}\right)$ evapotranspiration rate (provided $E_{p}$ is obtained by the Penman equation (1948), see Szilagyi and Jozsa (2009a)), defined by the Priestley-Taylor Eq. (1972). In other words

$E=2 E_{w}-E_{p}$,

where

$$
E_{w}=\alpha \frac{\Delta}{\Delta+\gamma} Q_{n}
$$

with $\Delta$ being the slope of the saturation vapor pressure curve at the temperature of the air, $\gamma(\approx 0.67$ $\mathrm{hPa} \mathrm{K} \mathrm{K}^{-1}$ ) the psychrometric constant, and $\alpha$ the Priestley-Taylor coefficient with typical values around 1.2 - 1.3. Penman (1948) defined $E_{p}$ as

$$
E_{p}=\frac{\Delta}{\Delta+\gamma} Q_{n}+\frac{\gamma}{\Delta+\gamma} f(u)\left(e^{*}-e\right)
$$

where $e$ and $e^{*}$ is the actual and saturation vapor pressure at the temperature of the air, respectively, and the wind function, $f(u)$ is defined as

$$
f(u)=0.26\left(1+0.54 u_{2}\right)
$$

with $u_{2}\left[\mathrm{~m} \mathrm{~s}^{-1}\right]$ being the mean horizontal wind velocity measured at 2-m height above the ground.

While the Advection-Aridity (AA) model of Brutsaert and Stricker (1979) employs the above definitions for the different terms in Eq. (1), Morton et al. (1985) in their WREVAP model specify $E_{p}$ and $E_{w}$ differently, but in a way that Eq. (1) is still valid (Szilagyi and Jozsa, 2008). They suggest Eq. (1) to be employed for time-periods equal or longer than about a week for improved accuracy. This is so because the CR is based on an assumed equilibrium state of the atmosphere and the underlying land, the latter influencing the humidity of the air through ET regulated by various feedbacks across the land-atmosphere interface. To attain such an equilibrium takes some time following each weather fronts passing through the area.

Recently Eq. (1) has been applied in numerous regional to continental-scale studies ranging from specifying long-term mean ET across the US (e.g., Hobbins et al., 2001a,b) to identifying long-term trends in the ET rates (Szilagyi, 2001) to investigating the global hydrologic cycle (Brutsaert and Parlange, 1998).

While the above studies yield regionally representative values of ET, none of them attempted to account for the spatial variability of ET within the region. Recently however Szilagyi and Jozsa (2009b) proposed such a disaggregation scheme utilizing Moderate Resolution Imaging Spectroradiometer (MODIS) data that have a nominal spatial resolution of about $1 \mathrm{~km}$. Here their approach is employed with several modifications as well as generalizations (explained later) making it more flexible to use.

\section{Model description}

Spatial disaggregation of the regionally representative ET rates of Eq. (1) (employing the AA or WREVAP models or the wet-surface equation ( $\mathrm{Szi}$ lagyi and Jozsa, 2009b, c)) is based on a linear transformation (Szilagyi and Jozsa, 2009b) of the 8day composited (for eliminating cloud effects by retaining the warmest pixel value in each 8-day period) MODIS daytime surface temperature $\left(T_{s}\right)$ values into actual ET rates. See the MODIS website 
(http://modis.gsfc.nasa.gov/) for more details of data collection and characteristics. The transformation requires the specification of two anchor points in the $T_{s}$ - ET plane (Fig. 1). The first anchor point is defined by the spatially averaged daytime surface temperature, $\left\langle T_{s}\right\rangle$, and the Eq. (1) obtained $E$ values. The second anchor point results from a spatial averaging of the coldest pixel values, $\left\langle T_{s w}\right\rangle$, within the region and $E_{w}$ of Eq. (2) out of consideration that the coldest pixels are the wettest evaporating at the wet environment evapotranspiration rate, $E_{w}$. The two points define the linear transformation of the $T_{s}$ pixel values into ET rates for each 8-day period, or for, as was done by Szilagyi and Jozsa (2009b), each month by employing monthly means.

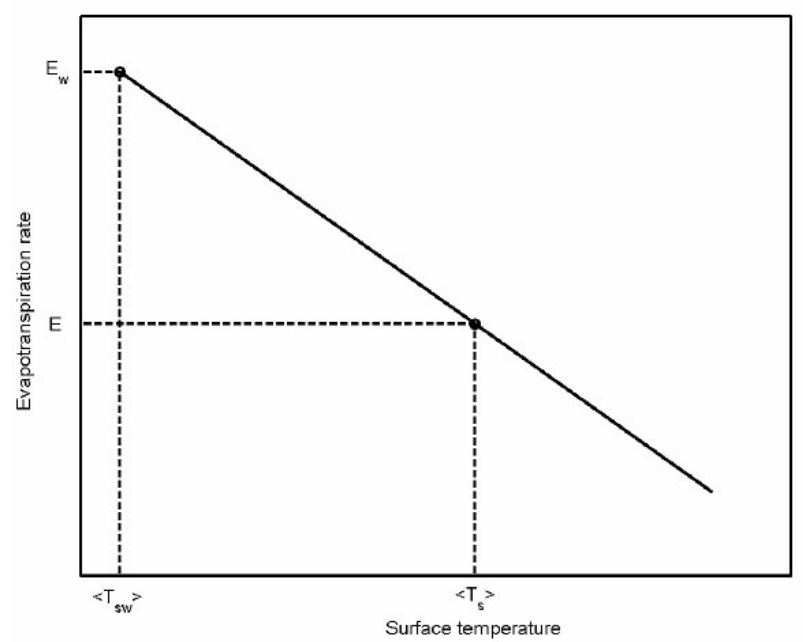

Fig. 1. Schematic representation of the linear transformation of the MODIS daytime surface temperature $\left(T_{s}\right)$ values $\left[{ }^{\circ} \mathrm{C}\right]$ into $\mathrm{ET}(E)$ rates $[\mathrm{mm} / \mathrm{mo}]$.

Although the linear transformation of Szilagyi and Jozsa (2009b) was derived independent of the widely popular and successful ET-estimation models of SEBAL (Bastiaanssen et al., 1998) or METRIC (Allen et al., 2007), it can be justified for the same reasons that are behind these latter approaches. Namely, the surface-air temperature difference can be assumed to be linearly dependent of the surface temperature (Bastiaanssen et al., 1998; Allen et al., 2007), thus the sensible heat $(H)$ transfer across the land-atmosphere interface can also be taken a linear function of $T_{s}$ (Bastiaanssen et al., 1998; Allen et al., 2007), provided changes in the aerodynamic resistance $\left(r_{a}\right)$ among MODIS pixels are moderate. This can be so because under neutral atmospheric conditions (attained for time-steps a day or longer) $r_{a}$ depends linearly on the logarithm of the momentum roughness height, $z_{0 m}$ (Allen et al., 2007), thus any change in $z_{0 m}$ between pixels becomes significantly dampened in the $r_{a}$ value. Then, under a spatially constant $Q_{n}$ term required by the CR, the latent heat $(L E)$ transfer itself becomes a linear function of $T_{s}$, since the soil heat flux is generally negligible for intervals longer than a day, therefore $Q_{n}=H+L E$ from which $L E=a T_{s}$ $+b, a$ and $b$ being constants for the computational time step, i.e., a month here.

While a spatially constant $Q_{n}$ term may seem an overly stringent requirement in practical applications due to spatial changes in vegetation cover, the linear transformation of $T_{s}$ into $E$ values on a pixelby-pixel basis can still be justified as long as $Q_{n}$ changes only negligibly between the pixels which requires that the surface albedo (as well as the mean slope and aspect of the land surface) also changes negligibly among the pixels. The spatially constant $Q_{n}$ (and to a lesser extent $z_{0 m}$ ) requirement thus limits the spatial resolution the current method can be applied at, since by decreasing the pixel size, heterogeneity among the cells likely increases. Below we show that at least for the study area, the country of Hungary, the MODIS pixel size of about $1 \mathrm{~km}$ ensures a largely constant $Q_{n}$ value among the pixels due to only small observed spatial changes in the surface albedo when derived on a monthly basis.

\section{Model application}

8-day composited MODIS daytime surface temperature data for 2000-2008 were collected for Hungary, situated in East-Central-Europe. The 8-day composited pixel values were averaged (any suspiciously low pixel value discarded) for each month to obtain one surface temperature per pixel per month. Such an averaging further reduces any possible cloud contamination effect that may remain in the 8-day composited images. From the Hungarian Meteorological Service (HMS) 0.1-degree gridded mean monthly air temperature and specific humidity data were collected for the same period as well as sunshine duration values from 15 stations spread across the country which subsequently were interpolated to the same 0.1degree grid. With these data, the linear transformation of mean monthly $T_{s}$ values into monthly ET rates can be performed on a (MODIS) pixel-bypixel basis. For validation purposes a) 0.1-degree gridded precipitation $(P)$ data from HMS; b) stream discharge $(R o)$ values from the Water Resources Research Center (VITUKI), the University of West 
Hungary (NYME) and the Regional Water Authorities (RWA) for selected watersheds (Fig. 2); c) eddy-covariance (EC) measurements of latent heat fluxes from HMS and the CarboEurope web-site (www.carboeurope.org) (Fig. 2); d) lake evaporation measurements/estimates for Hungary's large shallow lakes (Balaton, Ferto, Velencei) from VITUKI and RWA were also collected.

The country due to its relatively small size was considered as one region which means that the linear transformation is valid for the whole country in the absence of elevation changes. However, with elevation (Fig. 3a), surface temperatures are expected to decrease independent of whether a pixel is wet or not. Therefore, the country was subdivided into three elevation zones: below $200 \mathrm{~m}$, between 200 and $500 \mathrm{~m}$, and above $500 \mathrm{~m}$ (Fig. $3 b)$. The anchor points of the linear transformation were calculated separately for the three zones each month by a) calculating the spatial average of the MODIS-pixel surface temperatures within each zone and the corresponding regional evaporation rate, $E$, with the help of the WREVAP program for which the input variables were the spatially averaged values of the 0.1-degree gridded air tempera- ture, specific humidity and sunshine duration values within the zone; b) calculating the wet-environment evaporation rate, $E_{w}$, within the zone by (2) via the WREVAP-obtained $Q_{n}$ value plus taking the mean of the coldest 30-50 (30 in the highest region) MODIS pixels from the middle part (i.e., 300-400 $\mathrm{m}$ and $550-650 \mathrm{~m}$, for the latter it was considered that the area vanishes fast with elevation) of the elevation zone. For the lowest zone no such middle part was defined due to the small change in elevation. As Szilagyi and Jozsa (2009b) demonstrated, the method is not sensitive to the exact number of cold pixels employed. Note that only the zoneaveraged values of the 0.1 -degree gridded meteorological data are needed for defining the anchor points, thus no matching of the MODIS and the 0.1 -degree grid is required.

In order to not have possible sharp changes in the resulting pixel ET rates between the zones, the transformation equation was allowed to change linearly with pixel-elevation $(z)$ between the limiting equations of the lower $(l)$ and upper $(u)$ zones. Mathematically,

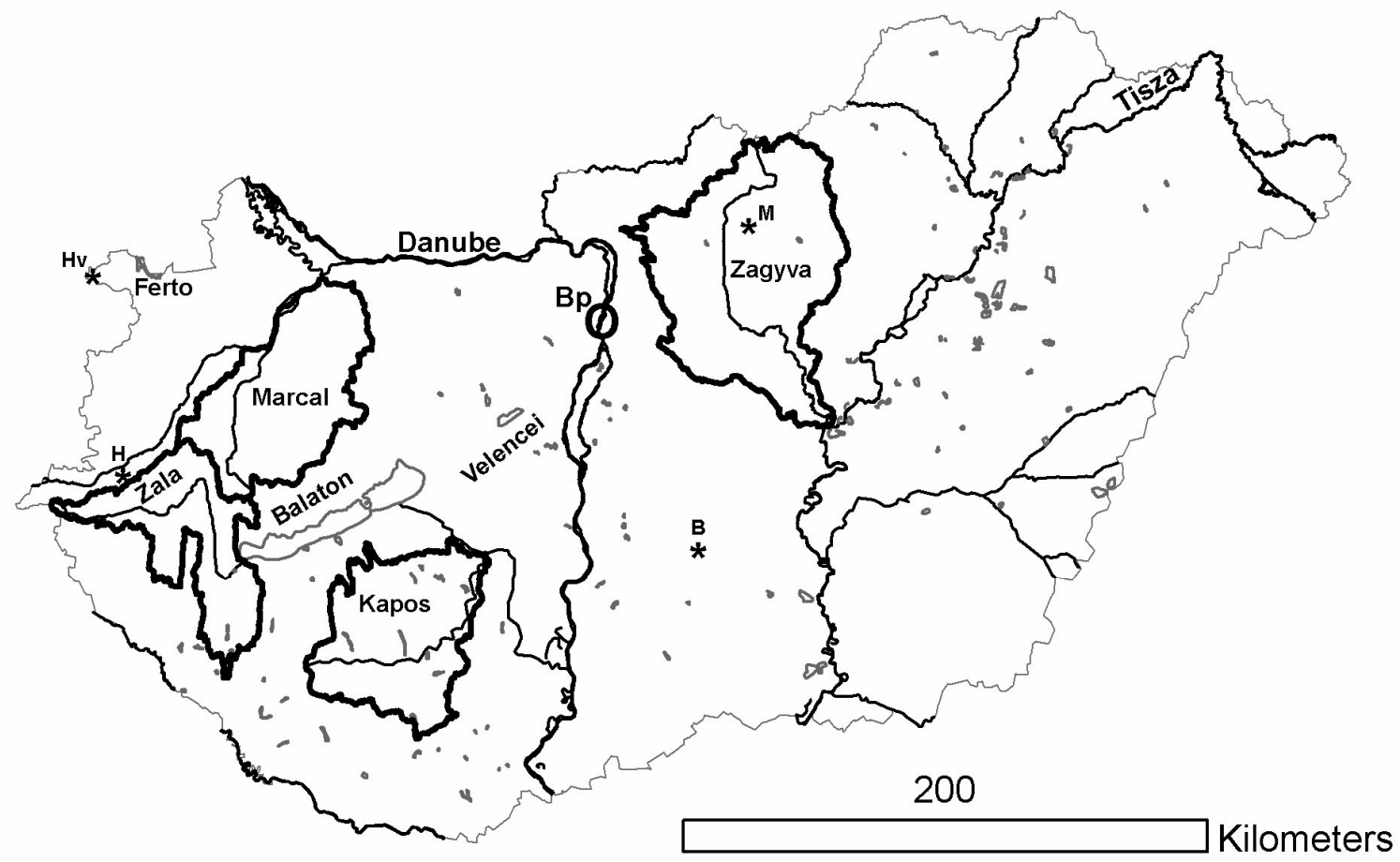

Fig. 2. Location of the watersheds [Kapos, Marcal, Zala, Zagyva and Hidegvizvolgy (Hv)] and eddy-covariance towers [Bugac (B), Matra (M), and Hegyhatsal (H)] used for validating the model estimates. The actual catchment areas specified in Tab. 1 are somewhat smaller than here displayed due to the distance of the last downstream gauging station from the confluence. The largest natural shallow lakes (denoted by green polygons, e.g., Balaton, Lakes Ferto and Velencei) of Hungary and the capital, Budapest (Bp) are also identified. 

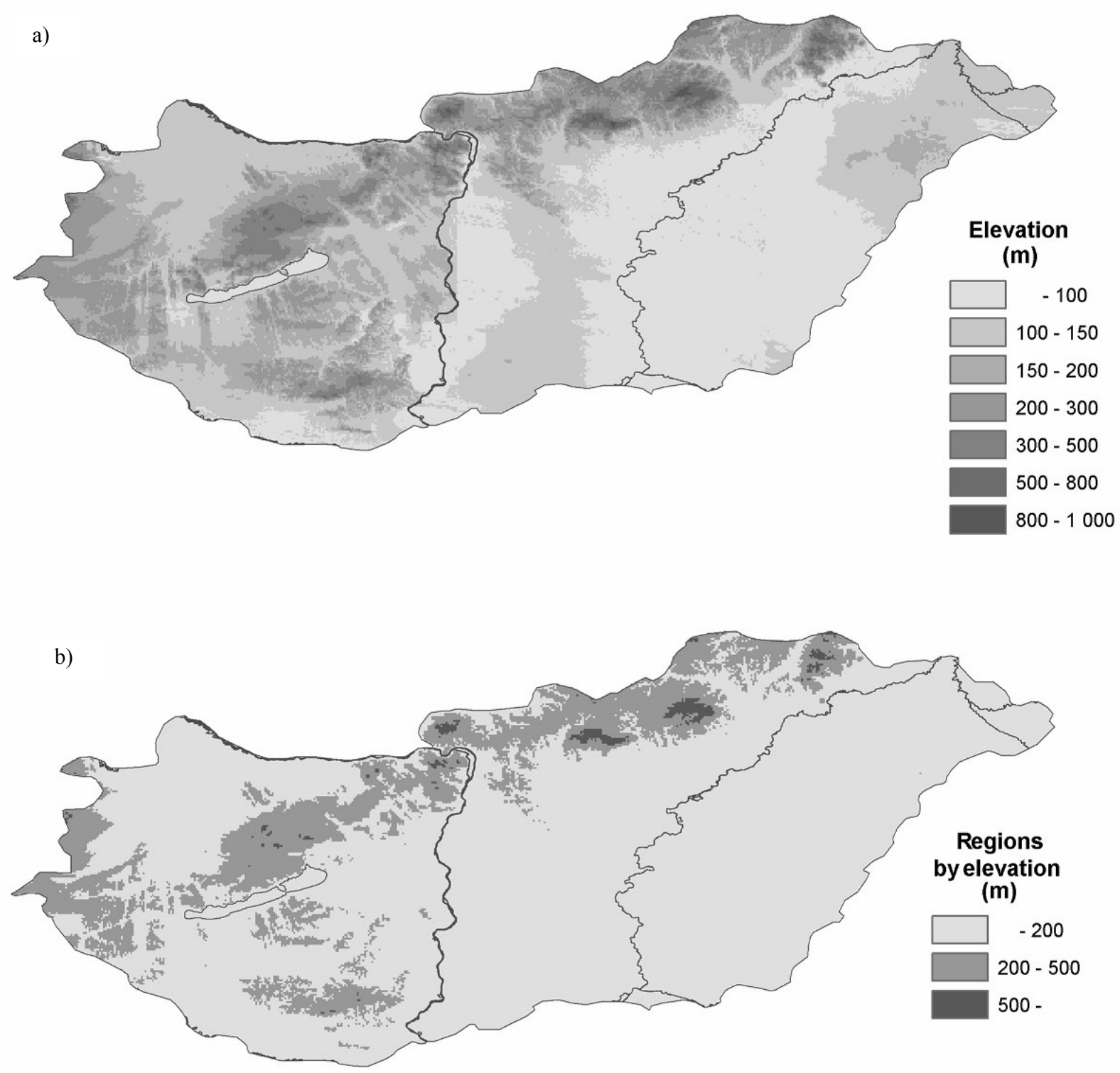

Fig. 3a) 1-km digital elevation model of Hungary; b) the extent of the three elevation zones employed in the model.

$\operatorname{ET}(z)=\frac{\left(z_{u}-z\right)\left[a_{l} T_{S}(z)+b_{l}\right]+\left(z-z_{l}\right)\left[a_{u} T_{S}(z)+b_{u}\right]}{z_{u}-z_{l}}$

where $a$ and $b$ are the parameters of the linear transformations by zone, obtained with the help of the anchor points. Here the reference elevations $\left(z_{u}\right.$ or $\left.z_{l}\right)$ are taken at 100, 350, and 600 meters.

Fig. 4 displays the linear transformations by months for the lowest zone (i.e., under $200 \mathrm{~m}$ ). The line sections are bounded by the anchor points illustrated in Fig. 1 but during the calculations they are allowed to extend downward to accommodate for pixels warmer than the zonal-mean. Occasionally the transformation may yield negative pixel-ET values for very warm pixels which then were replaced by zeros. The lines, however, are bounded from above, i.e., in the few occasions (about half the number of the coldest points considered) when the pixel temperature is lower than $\left\langle T_{w s}>\right.$, the corresponding ET value assigned is still $E_{w}$.

The transformations were not performed for the winter months (December, January, and February) because then the ground may have patchy snow cover (or the mountainous areas have snow but the lower grounds do not) which violates the constant $Q_{n}$ assumption since the albedo of snow is markedly different from that of the land. This is not a 
serious restriction on the general applicability of the model since in temperate climates ET is very limited in the winter months anyway. In certain years the highest mountains in Hungary may still have some snow cover in March, their spatial extent, however, is limited.

Fig. 5 displays the distribution of MODIS-pixel albedo for August, 2004. The distribution is very narrow, with a standard deviation of $1.56 \%$ and mean of $15.1 \%$. This corroborates the working hypothesis that $Q_{n}$ can be considered quasi-constant among the MODIS pixels. Other months display very similar narrow distributions. There is however a slight secondary peak at an albedo value of 5\%, corresponding to the large water bodies (mainly the natural shallow lakes of Balaton, Ferto, and Velencei) of the country. For these (and other lakes altogether ten - that are large enough to contain at least a few MODIS pixels within their areas) evaporation is calculated by the WREVAP program and thus the transformation ET values overwritten.

Tab. 1 displays the main characteristics of the ET validation sites and watersheds. Selection of the watersheds was limited mostly by data availability for the 2000-2008 period. Since the precipitation data (needed for back-calculating ET over the watershed as $P-R o$ ) provided by HMS is restricted to Hungary, only those watersheds could be considered that are fully within the country's boundary.

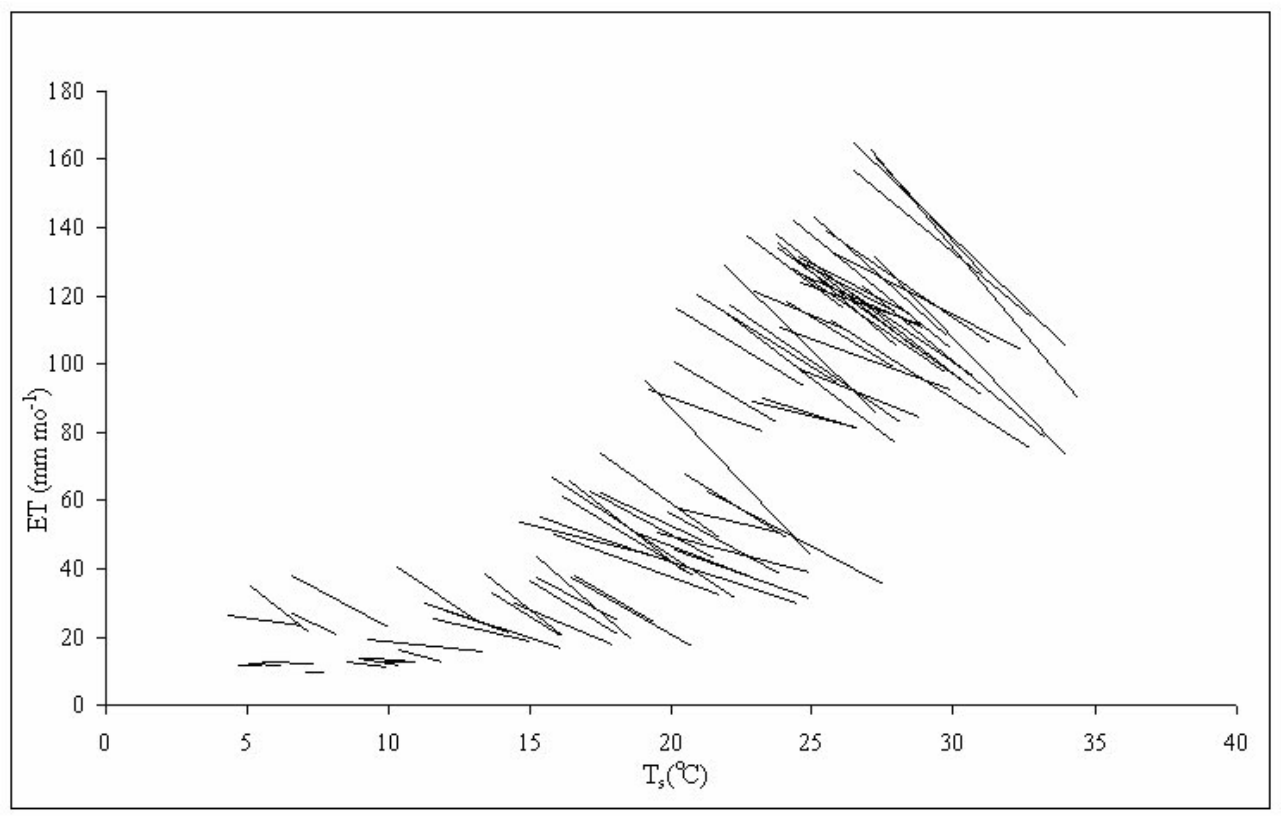

Fig. 4. Linear transformations for the lowest elevation zone, displayed by month for 2000-2008. Each line ends in the anchor points illustrated in Fig. 1. During the transformations each line is extended downward to accommodate for pixels warmer than the zonalmean.

$\mathrm{T}$ a b $1 \mathrm{e} 1$. Validation sites and watersheds, EC: eddy covariance. For the EC sites, area means the estimated (100 times the height of the instrument above ground) footprint size.

\begin{tabular}{lllcc}
\hline Location & Land cover & $\begin{array}{l}\text { Coordinates } \\
{[\text { lat }(\mathrm{N}), \text { long (E) }} \\
\text { degrees }]\end{array}$ & $\begin{array}{l}\text { Elevation } \\
{[\mathrm{m} \text { a.s.1. }]}\end{array}$ & $\begin{array}{l}\text { Area } \\
{\left[\mathrm{km}^{2}\right]}\end{array}$ \\
\hline $\begin{array}{l}\text { CarboEurope Bugac site } \\
\text { (4-m tall EC tower) }\end{array}$ & Grassland & $46.69,19.6$ & 113 & 0.16 \\
$\begin{array}{l}\text { CarboEurope Matra site } \\
\text { (3-m tall EC tower) }\end{array}$ & Vineyards/Orchards & $47.85,19.73$ & 300 & 0.09 \\
$\begin{array}{l}\text { Hegyhatsal (EC instrum. } \\
\text { at 82 m above ground) }\end{array}$ & Forest and cropland & $46.95,16.65$ & 248 & 67 \\
Hidegvizvolgy catchment & Forest & - & 284 (mean) & 6 \\
$\begin{array}{l}\text { Kapos catchment } \\
\text { Marcal catchment }\end{array}$ & Forest and cropland & - & 184 (mean) & 3210 \\
Zagyva catchment & Forest and cropland & - & 185 (mean) & 3042 \\
Zala catchment & Forest and cropland & - & 211 (mean) & 4207 \\
\hline
\end{tabular}




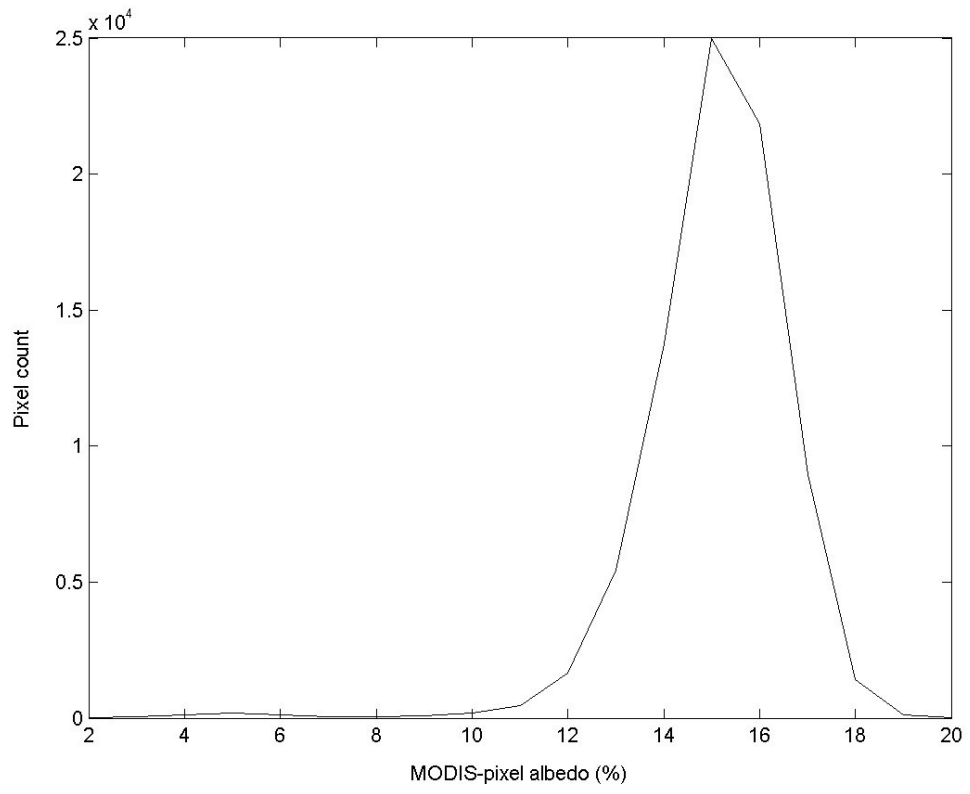

Fig. 5. Histogram of the MODIS-pixel albedo values for August, 2004.

\section{Results and discussion}

Fig. 6 displays the spatial distribution of the MODIS pixel $T_{s}$ values for a selected summer month. As expected, the open water bodies (lakes and rivers), the mountainous areas (typically with good forest cover), the lowland forests and wetlands are generally cooler than the rest of the land. Forests can easily be identified through a comparison with a composite global imagery scene (Fig. 7) from the same period (ESRI ancillary data for ARCGIS 9.3.1 documentation from www.esri.com) where they appear in vivid-to-dark green color. Even in the south-central region of Hungary, the unique sandy inter-fluvial plateau region of the Danube and its tributary the Tisza River, where the groundwater table has been documented to decline steadily over the past several decades (e.g., Szilagyi, 1994; Szilagyi and Vorosmarty, 1997), the forests (many of them the result of targeted reafforestation) can be identified by their reduced temperatures.

Fig. 8 displays the spatial distribution of the ET rates as period-averaged (2000-2008) annual values. This is possible because we postulated that ET in the three winter months (with mean air temperatures around the freezing point) is negligible. Again, a very close match is found with the landcover distribution of Fig. 7. Not surprisingly, the 'driest' continuous region is the sandy inter-fluvial plateau in south-central Hungary, the karst-plateau just north of Lake Balaton, and the urban conglomerate of Budapest (see the heat-island of Budapest in Fig. 6 in the north-central part of the country). The wettest regions are the tallest mountains with good forest cover and ample precipitation (Fig. 9) in the northern part of the country, the galleryforests along the main rivers (the largest is Gemenc, a natural protection area along the Danube in the south-central part), the wetlands (Kis-Balaton, immediately south-west of Lake Balaton, as well as areas around Lake Ferto in western Hungary), and the forests in the south-western part of the country where annual precipitation is most abundant, in excess of $800 \mathrm{~mm}$. The evaporation rates of the largest water bodies (about $890 \mathrm{~mm}$ ) were calculated by the WREVAP program with the winter months included since lake evaporation - provided the lakes do not freeze up - is typically not negligible even in cold temperatures. In two previous studies (Kovacs and Szilagyi, 2009a,b)) WREVAP has been shown to yield accurate estimates of lake evaporation. These evaporation rates are typically larger than the $T_{s}$-obtained values by about $10 \%$, caused mainly by the difference in the albedo values (Fig. 5) of the two surfaces. For the calculations the otherwise hard-to-locate WREVAP documentation with the original FORTRAN source code of Morton et al. (1985) can be downloaded from the personal web-site of the first author (snr.unl.edu/szilagyi/szilagyi.htm). 


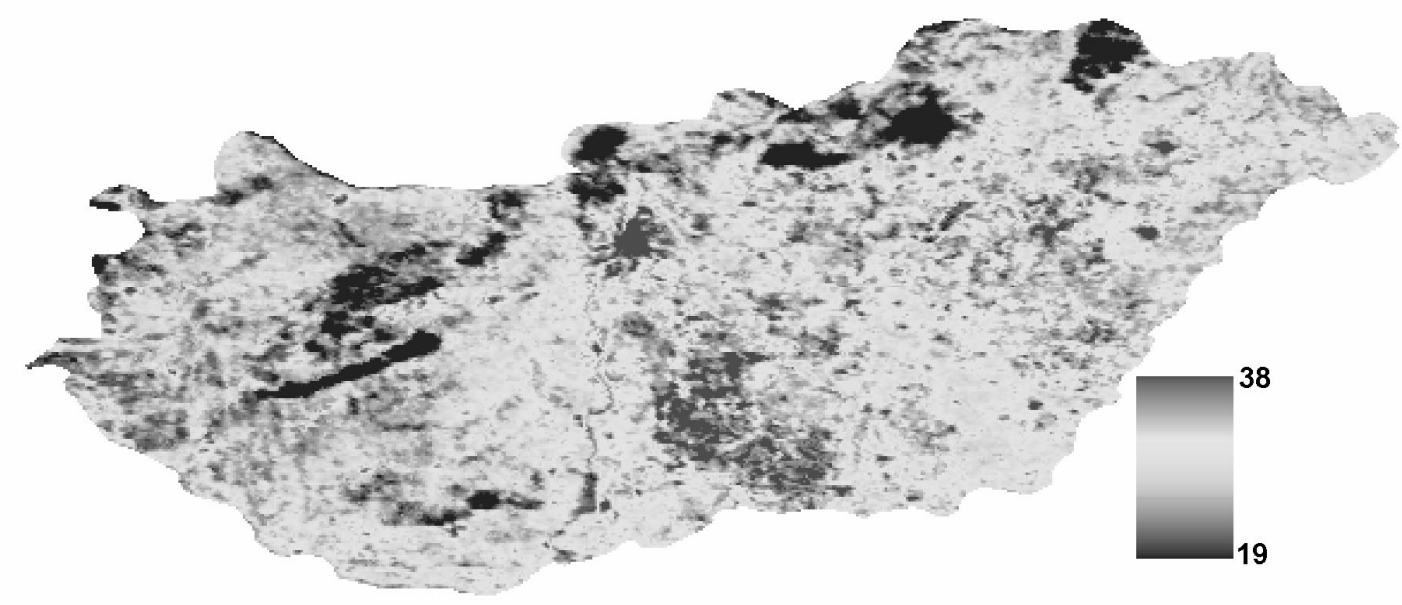

Fig. 6. Spatial distribution of the MODIS $T_{s}$ values $\left[{ }^{\circ} \mathrm{C}\right]$ in June 2008.

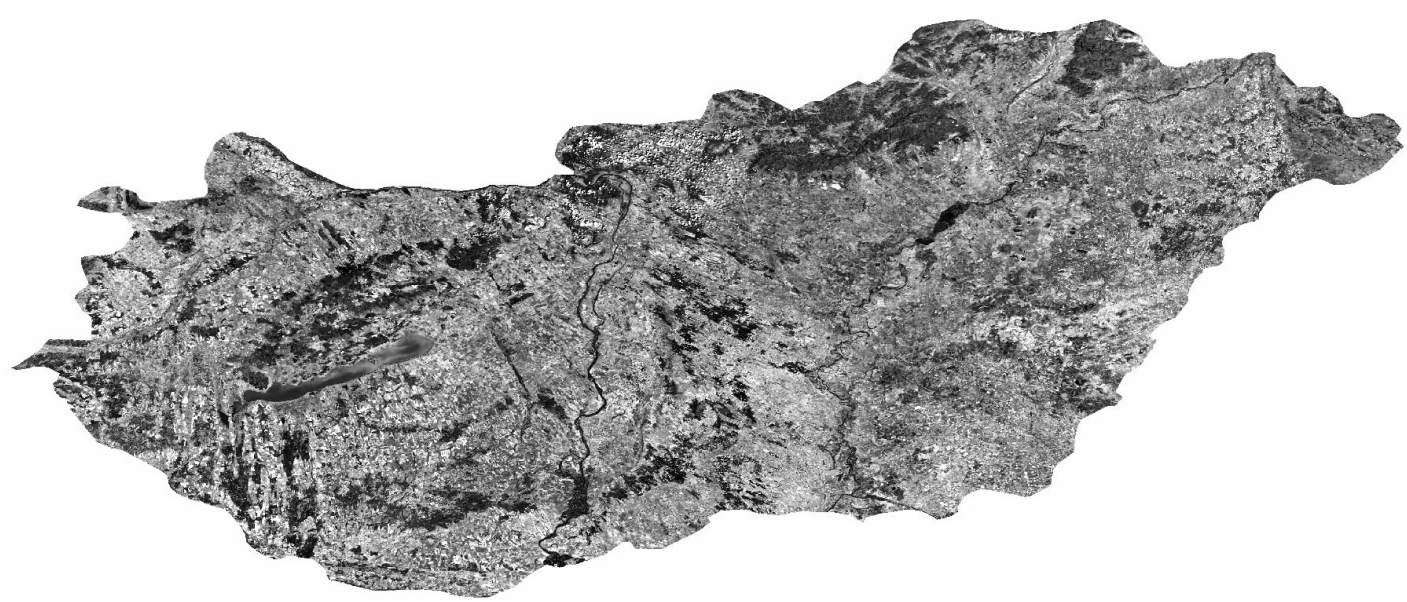

Fig. 7. Composite global imagery scene of Hungary. The forested areas show up in different shades of green.

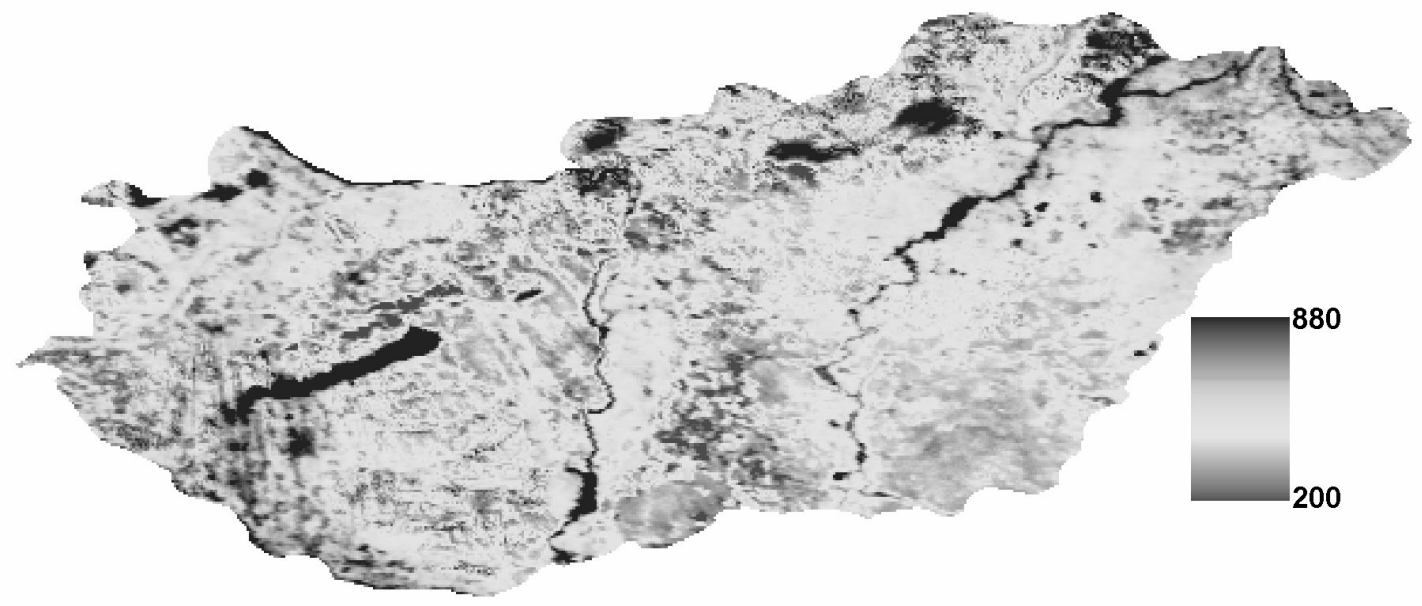

Fig. 8. 9-year averaged (2000-2008) mean annual ET rates [mm]. 


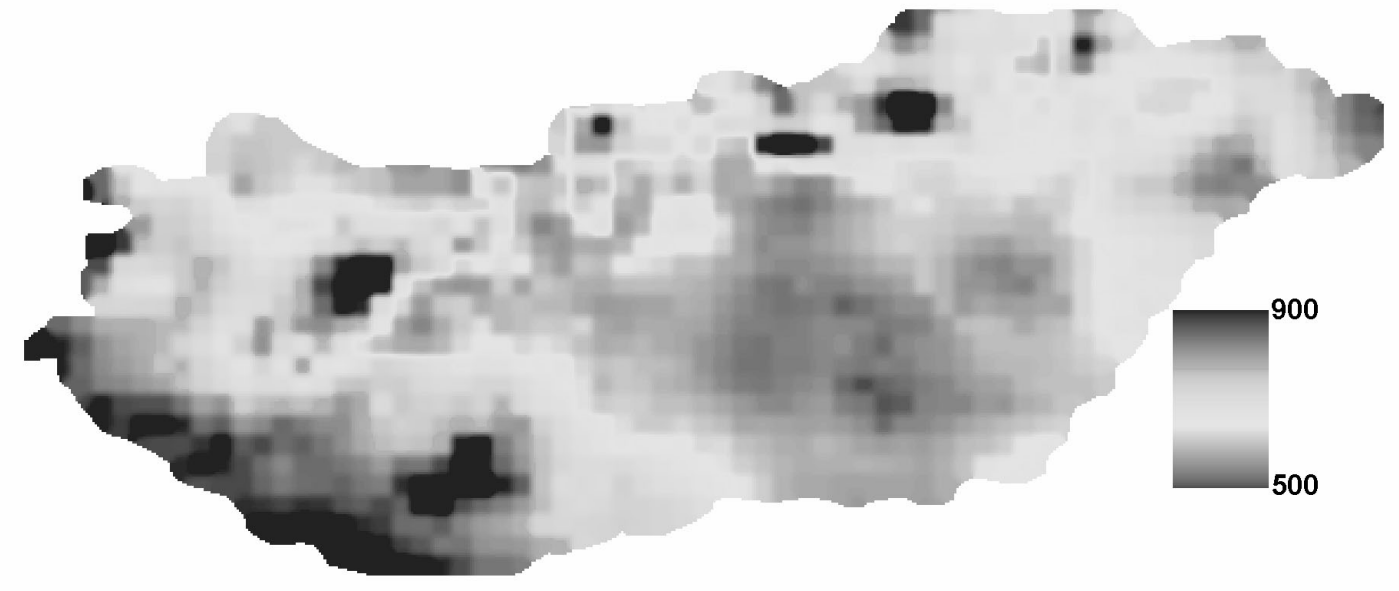

Fig. 9. 9-year averaged (2000-2008) and smoothed mean annual precipitation rates [mm] from the 0.1-degree gridded values.

Validation of the results were performed with the help of three eddy-covariance sites and five watersheds (Fig. 2 and Tab. 1). While continuous data from the two CarboEurope sites (Nagy et al., 2007; Pinter et al., 2008) were available for each month of our study period, from the third site, Hegyhatsal (Barcza et al., 2009), continuous measurements were available only for the selected months displayed in Fig. 10 which, together with Tab. 2, summarize the result of the validation.

The CREMAP ET values (averaged over $8 \times 8=$ $=64$ MODIS pixels around the tower) yield an unbiased estimates of the observed ET rates, provided the Hegyhatsal measurements are multiplied by 1.78 . This is necessary because the uncorrected eddy-covariance measurements represent a $44 \%$ systematic underestimation (Fig. 11) in comparison with energy balance closure. The $Q_{n}$ values were obtained from independent sources a) locally measured data provided by Z. Barcza, and b) WREVAP-model estimates based on 0.1-degree gridded sunshine duration measurements. The two $Q_{n}$ means are within $5 \%$ reinforcing the accuracy of the net radiation measurements at Hegyhatsal and the systematic underestimation of the EC instruments.

A $44 \%$ underestimation by the EC technique is somewhat larger than the generally accepted 10$-30 \%$ systematic undershoot (Baldocchi, 2003) well known for such systems. The unusually high location and placement $(82 \mathrm{~m}$ above ground on a $117-\mathrm{m} \mathrm{TV}$ transmitter tower) of the instruments (Barcza et al., 2009) may have contributed to the increased undershoot.

At the watershed-scale, validation is possible only in a multi-year sense because even at an an- nual basis water balance closure of $P-R o$ yields a highly uncertain estimate of ET due to the typically unknown changes in water storage within the catchment in the form of soil moisture and groundwater (Szilagyi and Jozsa, 2009b)). Period-averaged ET estimates are within a few percent of the waterbalance values, except at the Kapos catchment, where CREMAP undershoots water-balance ET by about $10 \%$. As can be seen in Fig. 2, this catchment contains the highest number of reservoirs (in fact more than is discernible from the map) having typically elongated shapes nested in the hilly terrain which are narrow enough so that they would not show up clearly in the $1-\mathrm{km}$ resolution MODIS pixels as low surface temperature areas. If the (not known) total surface area of such reservoirs is just $2 \%$ of the drainage area, then it would mean about a $4 \%$ increase in watershed ET due to the almost doubling of the latent heat fluxes between open water surfaces and the land (see Fig. 8). Therefore, the real undershoot in land area ET by CREMAP is probably less severe.

Fig. 12 displays the distribution of the multi-year (2000-2006) precipitation recycling index, the ratio of the mean annual ET and precipitation rates. The corresponding period is two years shorter than the study period because of the availability of water balance data for the whole country. When the pixel values are aggregated over the country the index becomes 0.892 versus the officially derived value of 0.896 for the same period, a remarkable match.

Figs. 8 and 12 convey important hydrologic information in a spatial detail never seen before in Hungary. To demonstrate the practical value of the $1-\mathrm{km}$ resolution ET maps in regional water 

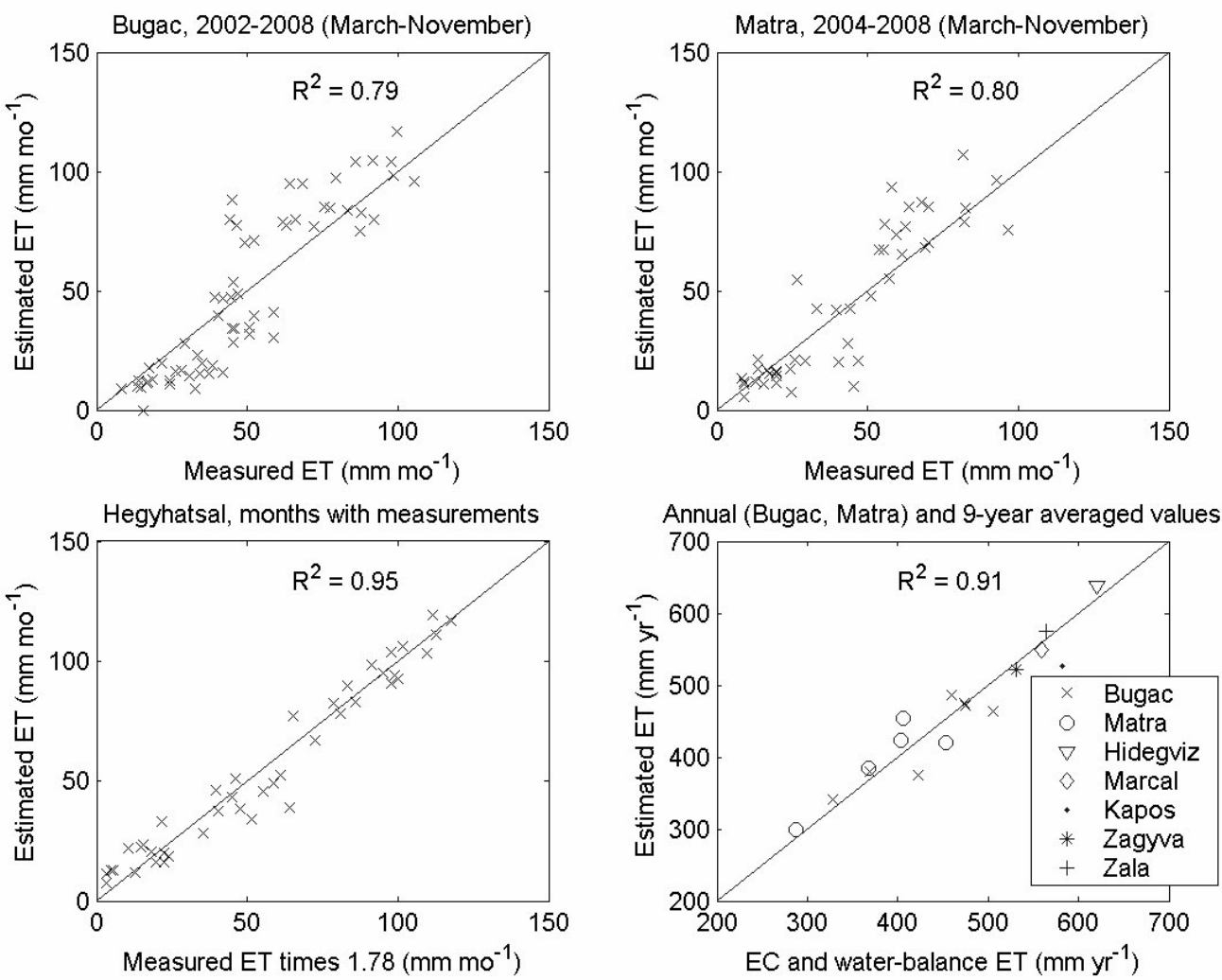

Fig. 10. Validation of the ET estimation method with eddy-covariance (Bugac, Matra and Hegyhatsal) and catchment water balance data. For the catchments precipitation values came from the 0.1-degree gridded values, except for the smallest watershed (Hidegvizvolgy) where precipitation was measured locally.

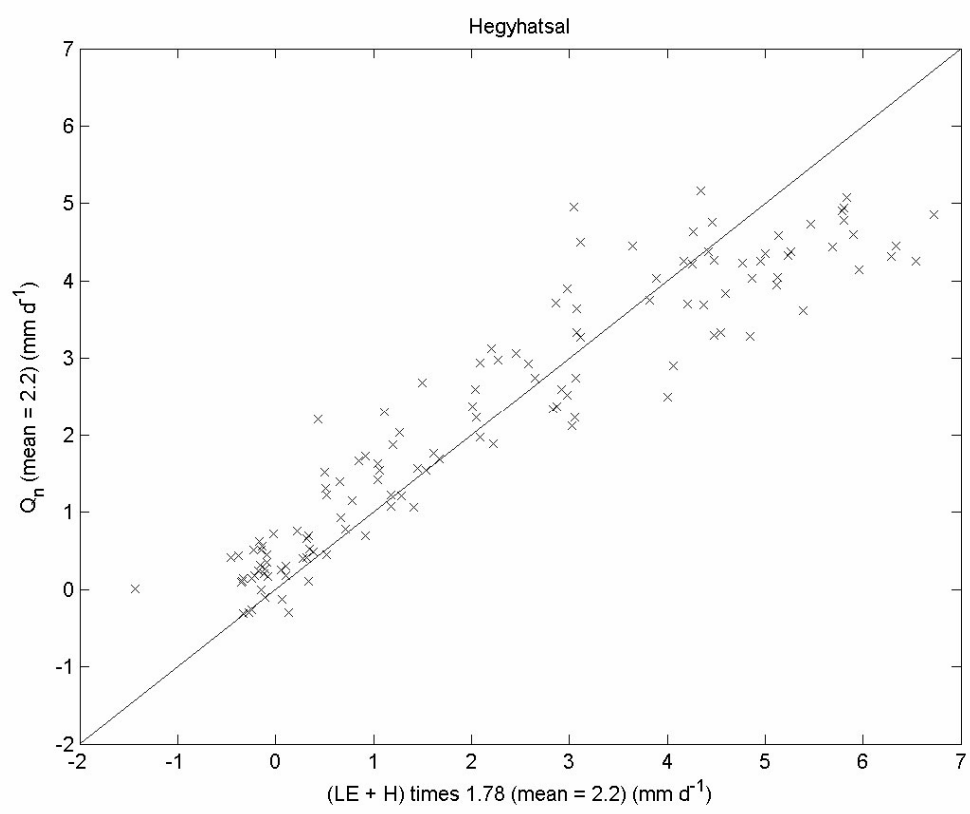

Fig. 11. Measured and (for missing days) modeled (Barcza et al., 2009) mean daily sums of the latent $(L E)$ and sensible $(H)$ heat fluxes versus measured mean daily net radiation $\left(Q_{n}\right)$ by month (January 1997 - December 2008) at Hegyhatsal, both expressed in water equivalent per day. 


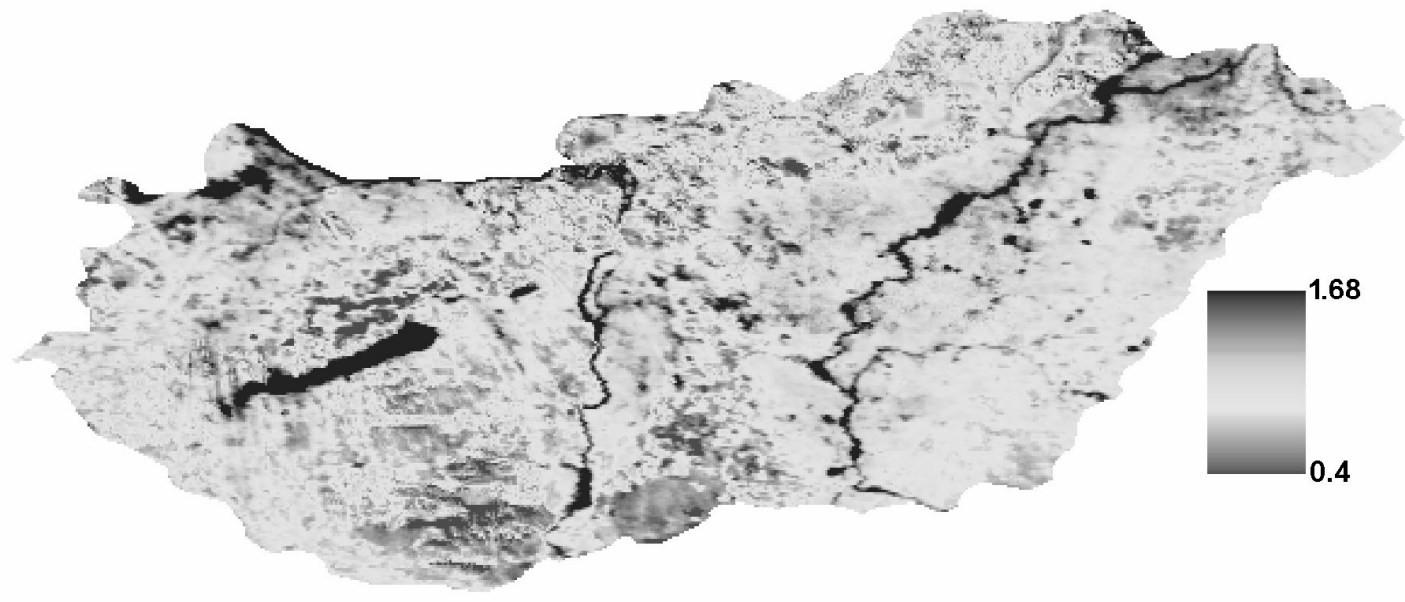

Fig. 12. Spatial distribution of the multi-year mean precipitation recycling index $(\mathrm{ET} / P)$ for 2000-2006.

resources management, let us have a look at what ET rates the maps predict for forested areas in the central inter-fluvial sand plateau region of the country, an area in focus for water resources managers due to the long-term groundwater decline (e.g., Szilagyi, 1994; Szilagyi and Vorosmarty, 1997) reported in the region. As can be seen from Figs. 11 and 7, large forested areas evaporate more (the index is larger than one) than the precipitation rate they receive. This is only possible, if the forests create a depression in the groundwater table, to induce local groundwater flow directed toward them which supplies the difference in ET and precipitation. In fact, this has been reported by Major (1976), in Stelczer (2000) from the region based on piezometer measurements, where they found that under the forest the groundwater table was on average $1 \mathrm{~m}$ deeper than in the surrounding nonforested areas. They calculated a mean annual ET rate of $712 \mathrm{~mm}$ for an actively growing black spruce community covering an area of $500 \times 500$ $\mathrm{m}$. On average the forest consumed $130 \mathrm{~mm}$ more water annually than it received from precipitation. Our figures match these findings, yielding an average $620 \mathrm{~mm}$ annual ET for the forests in the area (this value may go up to $650 \mathrm{~mm}$ in certain pixels), which is about $80 \mathrm{~mm}$ more than the mean annual precipitation rate of the region. Similar conclusion has been drawn by Szilagyi (1994) from a complex regional coupled surface water-groundwater balance model.

Since the model assumes a constant $Q_{n}$ term among the pixels, it may perform the worst in rugged, mountainous terrain, where the surface may express a predominant aspect (e.g., facing to the south) of medium-to-steep slopes, violating the constant $Q_{n}$ assumption. To modify the current model for such conditions requires further research. High (e.g., $90 \mathrm{~m}$ ) spatial resolution digital elevation or terrain models may be a good tool for the identification of such MODIS cells in the future.

\section{Summary and conclusion}

The present ET estimation model (CREMAP) is a modified and updated version of the ET estimation technique of Szilagyi and Jozsa (2009b) and utilizes 1-km 8-day composited MODIS daytime surface temperature, $T_{s}$, and basic atmospheric data (air temperature, humidity and sunshine duration) to estimate the latent heat flux at the same spatial and temporal scale. Here a monthly time-step was chosen, as typical of regional hydrologic modeling (e.g., Hlavcová et al., 2004). The approach is based on a linear transformation of the monthly MODIS $T_{s}$ pixel values into ET rates (Fig. 1). The anchor points of the transformation come from the a) regional ET rate of the complementary relationship and the corresponding spatial mean of $T_{s} ; \mathrm{b}$ ) Priestley-Taylor equation of wet environment ET and the corresponding spatial mean of the coldest points in the region. The resulting linear equation, valid always for the given computation interval only (i.e., month), then applied for each pixel. With each month a new transformation equation is obtained similarly (Fig. 4). The advantage of the present method over that of Szilagyi and Jozsa (2009b)) is that a) the regional evaporation rate is calculated by the WREVAP model which is easier to employ than the wet-surface equation of Szilagyi and Jozsa (2009b)) which needs daily maximum air temperature values in addition of the data require- 
ment of WREVAP, and b) the location of the open water surfaces for the estimation of $\left\langle T_{s w}\right\rangle$ is not needed, because the latter can be estimated as the mean of the coldest $T_{s}$ values each month.

The model was validated with monthly eddy covariance (EC) measurements plus catchment-scale water-balance closure data. The validation, spanning almost three magnitudes in spatial scale, indicated a favorable match between ET estimates and observations (Fig. 10, Tab. 2). Especially noteworthy is the strong linear correspondence and high accuracy of the ET estimates with high-tower mounted (82 $\mathrm{m}$ above ground) EC measurements of latent heat on a monthly basis. This may not be of chance, since at the other EC validation sites the EC instruments sample a smaller area than the size of the MODIS pixel, while here many MODIS pixels (several tens at least) fall within the footprint area of the EC instruments. The overall strong correspondence with measured ET values and unbiased nature of the ET estimates is maintained even at the annual and multi-annual level, where seasonality effects are eliminated.

The model is simple, requires only a minimum amount of typically easily accessible (MODIS website, and e.g. internet accessible re-analysis data for climate variables) data, and calibration free. From the first author's personal website documentation of the WREVAP program with its FORTRAN source code is also accessible. The WREVAP program can be applied separately to estimate evaporation (rather than ET) from pixels over extended (i.e., which show up clearly in the MODIS image) open water surfaces. Typically open water evaporation is in excess of the CREMAP estimate by about $10 \%$, mainly due to differences in albedo between the land and water.

Generally, the model is expected to work correctly in areas where the complementary relationship is valid (Szilagyi et al., 2009). It is not recommended to be applied in mountainous areas of rugged terrain or in areas with large surface-albedo changes above the 1-km resolution of the MODIS data. Also, due to its inherent assumptions (mainly a spatially constant $Q_{n}$ ), it is not recommended to be applied at a spatial resolution much finer than about $1-\mathrm{km}$.

Acknowledgments: This work has been supported by (a) the Hungarian Scientific Research Fund (OTKA, \#77364); (b) contribution of the Agricultural Research Division of the University of Nebraska; (c) the New Hungary Development Plan (Project ID: TÁMOP-4.2.1/B-09/1/KMR-20100002) in connection with the scientific program "Development of quality-oriented and harmonized $\mathrm{R}+\mathrm{D}+\mathrm{I}$ strategy and functional model at BME" project.

$\mathrm{T}$ a b $1 \mathrm{e}$ 2. Error (estimated minus measured value) analysis of the ET estimates; $m e$ : error mean, de: standard deviation of error, re: relative error [\%] defined as the ratio of the error mean and the measurement mean $(m v)$. Note that there is only one single period averaged value for each watershed, so there the mean results from one value.

\begin{tabular}{|c|c|c|c|c|c|c|c|c|c|c|c|}
\hline \multirow[t]{3}{*}{ Location } & \multicolumn{4}{|c|}{ Monthly $\left[\mathrm{mm} \mathrm{mo}^{-1}\right]$} & \multicolumn{4}{|c|}{ Annual $\left[\mathrm{mm} \mathrm{yr}^{-1}\right]$} & \multirow{2}{*}{\multicolumn{3}{|c|}{$\begin{array}{c}\text { Period-averaged } \\
{\left[\mathrm{mm} \mathrm{yr}^{-1}\right]}\end{array}$}} \\
\hline & $m v$ & me & $d e$ & re $[\%]$ & $m v$ & me & $d e$ & re [\%] & & & \\
\hline & & & & & & & & & $m v$ & me & re [\%] \\
\hline Bugac & 50 & -0.7 & 16.1 & $\begin{array}{l}-1.4 \\
\end{array}$ & 433 & -6 & 28.3 & -1.4 & & - & \\
\hline Matra & 43 & 1.4 & 14.1 & 3.3 & 384 & 12.6 & 29.2 & 3.3 & & - & \\
\hline Hegyhatsal*) & 55 & 0.1 & 7.9 & 0.2 & & & - & & & - & \\
\hline Hidegvizvolgy & & & - & & & & - & & 620 & 18 & 2.9 \\
\hline Kapos & & & - & & & & - & & 582 & -56 & -9.6 \\
\hline Marcal & & & - & & & & - & & 559 & -10 & -1.8 \\
\hline Zagyva & & & - & & & & - & & 531 & -9 & -1.7 \\
\hline Zala & & & - & & & & - & & 564 & 11 & 1.9 \\
\hline
\end{tabular}

${ }^{*}$ The measured values are multiplied by 1.78 due to the systematic uncorrected undershoot of the EC data.

\section{REFERENCES}

ALLEN R.G., TASUMI M., TREZZA R., 2007: Satellitebased energy balance for mapping evapotranspiration with internalized calibration (METRIC)-model. J. Irrig. Drainage Engng., 133, 4, 380-394.

BALDOCCHI D.D., 2003: Assessing the eddy covariance technique for evaluating carbon dioxide exchange rates of ecosystems: past, present and future. Global Change Biol., 9, 1-14.

BARCZA Z., KERN A., HASZPRA L., KLJUN N., 2009: Spatial representativeness of tall tower eddy covariance measurements using remote sensing and footprint analysis. Agric. Forest Meteor., 149, 795-807.

BASTIAANSSEN W.G.M., MENENTI M., FEDDES R.A., HOLTSLAG A.A.M., 1998: A remote sensing surface en- 
ergy balance algorithm for land (SEBAL): 1. Formulation. J. Hydrol., 212, 198-212.

BOUCHET R.J., 1963: Evapotranspiration reelle, evapotranspiration potentielle, et production agricole. Annal. Agronom., 14, 543-824.

BRUTSAERT W., PARLANGE M.B., 1998: Hydrologic cycle explains the evaporation paradox. Nature, 396, (6706), 30

BRUTSAERT W., STRICKER H., 1979: An AdvectionAridity approach to estimate actual regional evapotranspiration. Water Resour. Res., 15, 443-449.

GUSEV Y., NOVÁK V., 2007: Soil water - main water resources for terrestrial ecosystems of the biosphere. J. Hydrol. Hydromech,. 55, 1, 3-15.

HLAVČOVÁ K., KALAŠ M., KOHNOVÁ S., SZOLGAY J., 2004.: Modelling potential evapotranspiration and runoff in monthly time step in the Hron River basin. (In Slovak.) (Modelovanie potenciálnej evapotranspirácie a odtoku v mesačnom kroku na povodí Hrona.) J. Hydrol. Hydromech., 52, 4, 255-266.

HOBBINS M.T., RAMIREZ J.A., BROWN T.C., 2001a): The complementary relationship in estimation of regional evapotranspiration: An enhanced advection-aridity model. Water Resour. Res., 37, 5, 1389-1403.

HOBBINS M.T., RAMIREZ J.A., BROWN T.C., CLAESSENS L.H.J.M., 2001b): The complementary relationship in estimation of regional evapotranspiration: The complementary relationship areal evaporation and advection-aridity models. Water Resour. Res., 37, 5, 1367-1387.

KOVACS A., SZILAGYI J., 2009a): Estimating evaporation rates of shallow great lakes in Hungary, I. (In Hungarian.) Hidrol. Kozlony, 89, 2, 47-50.

KOVACS A., SZILAGYI J., 2009b): Estimating evaporation rates of shallow great lakes in Hungary, II. (In Hungarian.) Hidrol. Kozlony, 89, 2, 51-56.

MAJOR P., 1976: Groundwater balance investigations in flat lands. 2. Piezometer readings. (VITUKI report, in Hungarian), VITUKI, Budapest.

MORTON F.I., 1983: Operational estimates of areal evapotranspiration and their significance to the science and practice of hydrology. J. Hydrol., 66, 1, 1-76.

MORTON F.I., RICARD F., FOGARASI S., 1985: Operational estimates of areal evapotranspiration and lake evaporation - Program WREVAP. National Hydrological Research Institute Paper \#24, Ottawa, Ontario, Canada.

NAGY Z., PINTER K., CZOBEL S., BALOGH J., HORVATH L., FOTI S., BARCZA Z., WEIDINGER T., CSINTALAN Z., DINH N.Q., GROSZ B., TUBA Z., 2007: The carbon budget of semi-arid grassland in a wet and a dry year in Hungary. Agric. Ecosyst. Environ. 121, 1-2, 21-29.

NOVÁK V., 2001: Evapotranspiration from Crop Canopies and its Distribution over the Territory of Slovakia. Pollution and Water Resources, Columbia University Seminar Proceedings, Columbia University, 375-397.

NOVÁK V., MATEJKA F., 2000: Vzt'ah medzi vlhkost'ou, vlhkostným potenciálom pôdy a intenzitou evapotranspirácie: výsledky matematickeho modelovania. (In Slo- vak.) (Soil water content, soil water potential and evapotranspiration interrelations: results of mathematical modeling.) J. Hydrol. Hydromech., 48, 2, 125-141.

PARAJKA J., SZOLGAY J., MÉSZÁROS I., KOSTKA Z., 2004: Grid-based mapping of the long-term mean annual potential and actual evapotranspiration in upper Hron River basin. J.Hydrol. Hydromech., 52, 4, 239-254.

PENMAN H.L., 1948: Natural evaporation from open water, bare soil, and grass. Proc. Royal Soc. London, A193, 120 $-146$.

PINTER K., BARCZA Z., BALOGH J., CZOBEL S., CSINTALAN Z., TUBA Z., NAGY Z., 2008: Interannual variability of grasslands' carbon balance depends on soil type. Community Ecol., 9 (Suppl1), 43-48. doi: 10.1556/ComEc.9.2008.S.7.

PRIESTLEY C.H.B., TAYLOR R.J., 1972: On the assessment of surface heat flux and evaporation using large-scale parameters. Month. Weather Rev., 100, 81-92.

STELCZER K., 2000: A vizkeszletgazdalkodas hidrologiai alapjai. (Hydological bases of water resources management. (In Hungarian.) ELTE Eotvos Kiado, Budapest, Hungary.

SZILAGYI J., 1994: Water-balance modeling in a changing environment: reductions in unconfined aquifer levels in the area between the Danube and Tisza Rivers in Hungary. Master's Thesis, University of New Hampshire, Durham, New Hampshire, USA

SZILAGYI J., 2001: Modeled areal evaporation trends over the conterminous United States. J. Irrig. Drainage Engng., 127, 4, 196-200.

SZILAGYI J., VOROSMARTY C.J., 1997: Water-balance modeling in a changing environment: reductions in unconfined aquifer levels in the area between the Danube and Tisza Rivers in Hungary. J. Hydrol. Hydromech., 45, 348-364 .

SZILAGYI J., JOZSA J., 2008: New findings about the complementary relationship based evaporation estimation methods. J. Hydrol., 354, 171-186.

SZILAGYI J., HOBBINS M., JOZSA J., 2009: A modified Advection-Aridity model of evapotranspiration. J. Hydrol. Engng., 14, 6, 569-574.

SZILAGYI J., JOZSA J., 2009a): Analytical solution of the coupled 2-D turbulent heat and vapor transport equations and the complementary relationship of evaporation. J. Hydrol., 372, 61-67.

SZILAGYI J., JOZSA J., 2009b: Estimating spatially distributed monthly evapotranspiration rates by linear transformations of MODIS daytime land surface temperature data. Hydrol. Earth System Sci., 13, 5, 629-637.

SZILAGYI J., JOZSA J., 2009c): An evaporation estimation method based on the coupled 2-D turbulent heat and vapor transport equations. J. Geophys. Res., 114, D06101, doi:10.1029/2008JD010772.

Received 27 April 2010 Accepted 23 June 2010 